\title{
Development of Tennis Learning Module Based on Blended Learning in Faculty of Sport Science, State University of Medan
}

\author{
Hariadi $^{1 *}$, David Siahaan ${ }^{2}$, and Ade Ros Riza ${ }^{3}$ \\ ${ }^{13}$ Study Program of Physical Education, Health and Recreation, Faculty of Sport Science, State University of Medan, \\ Medan, Indonesia \\ ${ }^{2}$ Sport Coaching Education Study Program, Faculty of Sport Science, State University of Medan, Medan, Indonesia \\ *Corresponding author. Email: hariadi@unimed.ac.id
}

\begin{abstract}
Modules as teaching materials that are systematic, interesting and can be used independently are expected to be a solution to the problem of the lack of teaching materials in Tennis course in Sport Science Faculty, State University of Medan. Students with different learning speed and skills ability learn them through modules according to their respective needs. The module developed in this study follows 4 development steps consisting of 1) needs analysis, 2) preparation of product drafts, 3) expert validation and legibility test, and 4) preparation of the final product. The results of expert validation for the module developed in this study shows a mean of $88 \%$ with very good category and the legibility test also showed very good results. Likewise, the response given by students to the final product of this module shows the number $89.9 \%$ in the very good category.
\end{abstract}

\section{Keywords: Module, Blended Learning, Tennis}

\section{INTRODUCTION}

Rapid progress and change in the community forced students preparing to meet the needs of society and industry 4.0. (Khatarina, et.al, 2016). One of the way is by building a collaborative virtual learning environment. The educational response to the needs of the industrial revolution 4.0 is called Education 4.0., where humans and technology can create new possibilities (Anealka, 2018). There are nine trends that will be the characteristics in education 4.0, (Fisk, 2017) namely: first, learning can be done anytime and anywhere. Second, learning will be personal for each individual. Third, students have the option of determining how they learn. Fourth, students will be more directed to project-based learning. Fifth, students will be directed to a more practical thing (hand-on experience). Sixth, students will be directed to the interpretation of data, where students are given data and are expected to be able in analyzing with knowledge and reasoning. Seventh, each student will be conducted by different assessment. Eighth, students' opinion will be considered in designing and updating the curriculum. Ninth, students will become more independent in their learning process.

Facing the above challenges, currently Universitas Negeri Medan (Unimed) has provided an online learning system called SIPDA Unimed. In the period of learning from home in anticipation of COVID 19 that started in
March 2020, this application became an online learning center in Unimed environment. However, the results of the data conducted by the researchers showed the academic community of FIK Unimed both lecturers and students are the lowest users on this application. One of the problems faced by lecturers and students is the lack of teaching materials relevant to the online learning framework.

Tennis course is one of the courses taught in the Study Program of Physical Education, Health and Recreation (PJKR) Faculty of Sports Science (FIK) Unimed. By participating in this course, students are expected to play a game of tennis with basic technical skills in the form of grip, ready attitude and standing position, and basic strokes (forehand, backhand, volley, serve and smash). Thus, this course contains theoretical and practical materials. The problems faced in this course is the low skills of students in the practice material of tennis skills. Meanwhile. the theory material is quite satisfied. One of the sources of the problem is the lack of teaching materials, currently teaching materials available only from learning dictates. There are still not available proper teaching materials for practical skills, currently only using motion skills videos available on the internet.

One of the relevant teaching materials that can be provided is by using modules. Learning modules are systematically and interestingly structured teaching materials that include the content of materials, methods and evaluations that can be used independently to achieve the 
expected competencies (Anwar, 2010). With modules uploaded into Unimed's online learning system (SIPDA), it is expected that students will be able to download learning materials outside of the specified face-to-face hours. Modules used in basic motion skills learning are expected to contain steps of motion in relevant video. Thus, students can see the learning module of tennis skills equipped with repetitive motion skills videos, so that they can practice them independently. The module is expected to help students with different learning speeds and skills learn knowledge and motion skills on tennis courses according to their individual needs. Although all lecture materials can be given online, basic tennis technical materials is required to be given face-to-face to be able to perform demonstrations and correct motion mistakes made by students. Therefore, the most appropriate learning for this course is to use blended learning.

Looking at the issues outlined in previous sentences, it is considered necessary to develop print modules and online modules which can meet the learning objectives in tennis courses. The modules developed are expected to meet the demands of KKNI curriculum which is conceptually composed by six main parameters namely (a) science, (b) knowledge, (c) practical knowledge (knowhow), (d) skill, (e) affection, and (f) competency. By using the principles of module development standard, it is expected that a module that meets the requirements of blended learning modules will be obtained to improve the competence of students in tennis courses in particular.

\section{RESEARCH PROBLEMS}

In this study the highlights formulation of problems is how the development of blended learning-based modules on tennis learning in KKNI curriculum so that can be obtained learning modules that can improve the learning outcomes of PJKR FIK Unimed students.

\section{RESEARCH OUTCOMES}

The outcomes targeted in this study are print modules and online modules that are expected to be used to complement teaching materials on tennis courses and can be developed for other relevant courses. The online module is equipped with video learning steps of court tennis skills, basic techniques of tennis games, evaluation of the implementation of basic techniques performed by students independently. With this module it is hoped that students and those in need can use it to improve knowledge and skills in tennis court courses in particular.

\section{RESEARCH LITERATURE}

\subsection{Modules}

Modules are teaching materials systematically arranged with languages that are easy for students to understand, according to their age and level of knowledge so that they can study independently with minimal guidance from educators (Prastowo, 2012). Modules are part of a planned learning unit designed to assist students individually in achieving their learning goals (Sukiman, 2011). Students who have high speed in learning will be faster to overcome the material. Meanwhile, students who have low speed in learning can learn again by repeating parts that have not been understood until understood.

The approach to module learning using the student experience which will hopefully make it easier to understand the content of existing learning so that the competencies that are expected to be achieved. By learning using skill modules, students are easier to master the expected skills (Hedin and Kann, 2019). Research shows that students receive activities well in modulelearning, and assume that modules are innovative, flexible, useful and fun (Gaikwad, 2014). In addition, the use of modules in learning aims to allow students to learn independently without or with a minimum of lecturers. In learning, lecturers are only facilitators. This is in line with KKNI-based curriculum learning strategy so that the expected learning achievements of students after attending lectures can be achieved.

\subsection{Blended Learning}

Definition of blended learning was first put forward by Graham and Friesen (Bryan and Volchenkova, 2016) as an integration between face to face and online learning to help the learning experience by developing information and communication technology. According to Staker and Horn (Bryan and Volchenka, 2016), blended learning is a formal education program where students learn in part through the content and instruction of tasks online and students have control over the time, place and manner in which they learn some of this with online supervision.

Blended learning can also be interpreted as a teaching method that combines the most effective face-to-face teaching techniques and online interactive collaboration, both systems that function in constant correlation and form a single entity. Broadly, there are three definitions of blended learning commonly used: combining various intruktusional modes (or instructional media), combining several instructional methods, and the latter being between online and face-to-face (Charles, 2016).

In blended learning-based learning models, the online learning process is greater than face-to-face, about 30-79\% (Barkati and Annas, 2013). In the development of blended learning-based defense, with the calculation of effective learning time is 5 months, then face-to-face is done in 3-4 weeks. The remaining 4 months of students will self-study with web-based learning. In this period of self-study, several students gather with lecturers on the web according to the specified schedule. The face-to-face process is intended to facilitate every problem faced by students during their learning process. Modules used in learning can be electronic modules and web-based teaching materials that have been uploaded in unimed SIPDA (Online Learning System). In using SIPDA Unimed, some 
of the benefits gained by lecturers and students in using SIPDA Unimed can be seen in the following table:

Table 1. This caption has one line so it is centered.

\begin{tabular}{|l|l|}
\hline \multicolumn{1}{|c|}{ LECTURER } & \multicolumn{1}{c|}{ STUDENTS } \\
\hline $\begin{array}{l}\text { To develop syllaby } \\
\text { RPS and SAP) in } \\
\text { accordance with KKNI } \\
\text { curriculum }\end{array}$ & \multicolumn{1}{|c|}{ Access information } \\
\hline Upload lecture materials & $\begin{array}{l}\text { Download lecture } \\
\text { materials }\end{array}$ \\
\hline $\begin{array}{l}\text { Assigning assignments } \\
\text { to students }\end{array}$ & $\begin{array}{l}\text { Conducting transactions } \\
\text { of lecture tasks }\end{array}$ \\
\hline $\begin{array}{l}\text { Accept student } \\
\text { assignments }\end{array}$ & $\begin{array}{l}\text { Doing } \\
\text { assignments }\end{array}$ \\
\hline Create a test/quiz & Work on tests/quizzes \\
\hline $\begin{array}{l}\text { Providing Value } \\
\text { Miew achievements of } \\
\text { learning outcomes }\end{array}$ \\
\hline Monitor student activity & See attendance \\
\hline $\begin{array}{l}\text { Processing student } \\
\text { grades }\end{array}$ & $\begin{array}{l}\text { See the results of learning } \\
\text { achievements }\end{array}$ \\
\hline $\begin{array}{l}\text { Interact with students } \\
\text { and sesame lecturers } \\
\text { through discussion } \\
\text { forums and chats }\end{array}$ & $\begin{array}{l}\text { Interact with sesame } \\
\text { students and lecturers } \\
\text { through discussion } \\
\text { forums and chats }\end{array}$ \\
\hline
\end{tabular}

Due to the use of blended learning that applies high computer usage, competence using computers is required (Abubakar \& Adetimin, 2015) to avoid failure in applying technology in effective learning in education. Students are expected to have good computer literacy and skills. SIPDA Unimed can also be accessed by using a mobile phone by downloading the app.

Research by Goyal and Tambe (2015) using descriptive statistics shows improved learning using syllabuses and learning plans uploaded in Moodle. Learning also improves by sharing lesson materials, submitting assignments and using an existing calendar. The students in this study considered Moodle to be an effective educational tool.

\subsection{Tennis Court}

Tennis court courses are the compulsory course of choice in PJKR with a 2 credits load. The course as contained in book IV KKNI in PJKR. The description of the course is a course that examines the basic concepts of knowledge, skills and value system as well as attitude in the sport of tennis court games. This course provides knowledge and skills so that students can play tennis court sports properly and properly supported by knowledge, history, courts, fixtures, rules of the game / referee tennis court. By participating in this course, students are expected to play a game of tennis with basic technical skills in the form of grip, ready attitude and standing position, and basic strokes (forehand, backhand, volley, serve and smash). All of them can be applied through a system of values and commendable attitudes in daily life in the community (Hariadi, 2016). Based on the description, the achievement of learning tennis courses in accordance with the Semester Teaching Plan (RPS) is that after taking this lecture, it is expected that students have competence in terms of:

1. Able to properly explain the history, courts and tennis equipment, rules of the game and matches as well as the basic techniques of tennis strokes properly (cognitive)

2. Able to perform basic strokes of tennis in the form of; forehand, backhand, volley, serve and smash, as well as Being able to implement basic punches into the form of a game/match that is refereed well and properly. (skill).

3. Internalize academic values, norms, and ethics in learning that is shown through honesty, discipline, cooperation, self-reliance, joy, responsibility and social sensitivity (respect) in conducting and acting in people's lives.

In basic motion learning tennis courts needed a wellorganized learning where students have the obligation to repeat and or delve into the materials provided earlier on a regular basis, so that students can have the skills expected according to the purpose of learning. While independent activities are activities carried out by students without guidance from lecturers, but conducted alone or together according to their time. By using the online module, it is expected that students can master the basic motion skills needed in performing manipulative gestures. Research conducted by Damrah (2018) shows that the more basic motion skills a person has, will make it easier for the person to perform the learned sports skills. Therefore, the level of basic motion skills of students needs to be known early before learning the next sports skills, so that the objectiveness of the learning results can be obtained clearly.

Tennis court learning can be done with several learning models that match the materials studied. There is an influence of interaction between the learning model and eye-hand coordination on the grounstroke ability of the tennis court backhand (Wibowo, 2017). Blended learning is one of the learning that is considered effective in the learning of court tennis courses, because this course requires the practice of basic motion skills playing tennis. Students in a study by Osgerby (2013) had a positive perception of blended learning but preferred face-to-face with step-by-step instruction for practical activities, this corresponded to skill materials on tennis court courses that required demonstration and appearance from students.

\subsection{Module Development}

Developing modules means developing learning and teaching a subject through writing. Therefore, the principles used in developing modules are the same as those used in regular learning. The difference is that the language used is half formal and half-spoken, not a very formal textbook language. There are three techniques to 
choose from in compiling modules (Sungkono, 2012). The three techniques are self-writing, information repackaging, and information structuring.

Some research related to the use and development of modules in learning shows that modules can improve learning outcomes (Astiti et.al: 2014, Nyimas: 2011, Husna:2013, Rose: 2013), in addition, the module can also increase student activity and misconception reduction (Wagiran: 2016), as well as improve understanding of generic science concepts and skills (Septiani, et al: 2014).

\section{RESEARCH METHODOLOGY}

The development of this module uses a type of research and development research. Research and development methods are research methods used to produce a particular product, and test the effectiveness of the product. This type of research is different from other educational research because the goal is to develop products based on trials to then be revised to produce a viable product. Borg and Gall (Sugiyono, 2011) states that development research is a process used to develop and validate products used in education and learning.

The development stage of Dick \& Carey (2009) was adapted into this development research into 4 stages of module development, namely:

\section{Needs Analysis}

This stage aims to examine the purpose of the product to be developed. The product to be developed is a module. Researchers will conduct curriculum analysis to determine which products meet the demands of the curriculum. The needs analysis stage is carried out in several steps, among others: 1) Learning Achievement Analysis; 2) Analysis of Teaching Materials and 3) Analysis of Student Perception of Tennis Court Courses. This level of needs analysis is done through literature studies and focus group discussion (FGD) with several parties who have competence in terms of kkni curriculum and also lecturers in the department of Physical Education health and recreation (PJKR) Faculty of Sports Science (FIK) Unimed. Analysis of students' perception of Tennis Court courses was conducted by providing questionnaires to 50 students with random sampling techniques.

\section{Product design stage}

The results of the next needs analysis will determine the design of the product to be developed. Product design must be realized in an image or chart, so that it can be used as a handle to assess and create it (Sugiyono, 2012). The product design stage of its activities includes determining module components, the concept of material delivery and organizing, the type of task given, evaluation questions, images, articles, examples, and module layouts. This stage will result in the initial product design in the form of modules that have previously been done drafting product assessment instruments to serve as guidelines in designing products.

\section{Validation and evaluation stage}

This stage is the core stage in the form of a series of product development assessments. This stage was conducted by engaging materials experts and learning media consisting of 3 lecturers of Tenis in FIK Unimed environment. Analysis conducted by experts is used to see the level of quality of modules seen from three aspects namely 1) the substance of materials developed in modeul; 2) language aspect and 3) presentation aspect. To determine the results of the analysis of the instrument data has been prepared as many as 50 questions related to the feasibility of the media to be developed.

The next set of validation and evaluation stages is the readability test stage. Products that have been declared eligible by experts are then tested to a small group of PJKR FIK Unimed students as many as 10 people as potential users. Readability tests are carried out to get criticism and suggestions in order to improve the product.

\section{Final Product Stage}

This stage will result in the final product in the form of a revised module based on criticism and suggestions from the validation and evaluation stage. The final product is ready to be mass produced and deployed as a module in the learning process. In this study the development only reached the formative evaluation stage. The results of the formative evaluation are done as input or input to improve the initial product.

To facilitate understanding of the factors that play a role in improving student learning outcomes in Tennis Court courses can be described in the fish bone diagram as follows:

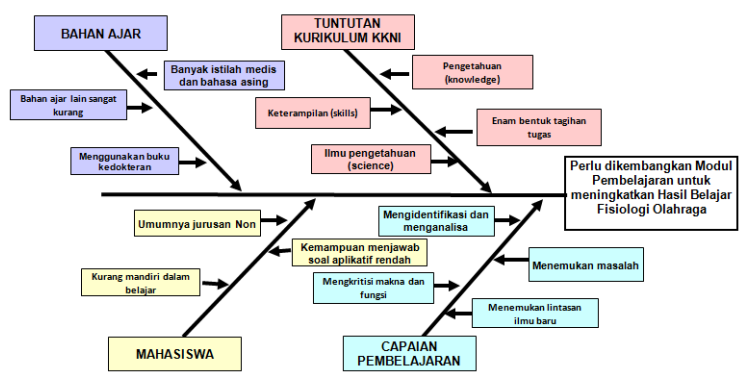

Figure 1. student learning outcomes in Tennis Court

\section{RESULT}

The development of this module uses a type of research and development research. Research and development methods are research methods used to produce a particular product, and test the effectiveness of the product. This type of research is different from other educational research because the goal is to develop products based on trials to then be revised to produce a viable product. Borg and Gall (in Sugiyono, 2011) states that development research is a process used to develop and validate products used in education and learning. 
The method used in this study follows the development stage of Dick \& Carey (2009). The method is adapted into this development research into 4 stages of module development, namely: the stage of needs analysis, product design, validation and evaluation as well as the final product stage.

\subsection{Stages of Needs Analysis}

This stage aims to examine the purpose of the product to be developed. The product to be developed is a module. Researchers will conduct curriculum analysis to determine which products meet the demands of the curriculum. The needs analysis stage is carried out in several steps, among others: 1) Analysis of Learning Achievements; 2) Analysis of Teaching Materials and 3) Analysis of Student Perception of Tennis Court Courses. This level of needs analysis is done through literature studies and focus group discussion (FGD) with several parties who have competence in terms of KKNI curriculum and also lecturers in the department of Physical Education health and recreation (PJKR) Faculty of Sports Science (FIK) Unimed. Analysis of students' perception of Tennis Court courses was conducted by providing questionnaires to 50 students with random sampling techniques.

\section{1) Analysis of Learning Achievements;}

Learning outcomes are internalization and accumulation of science, skills, attitudes, and competencies achieved through a structured educational process that covers a particular area of science/expertise or through work experience. learning that can meet the demands of kkni curriculum which is conceptually composed by six main parameters, namely (a) science, (b) knowledge (knowledge), (c) practical knowledge.

Tennis court courses are the compulsory course of choice in PJKR Unimed with a 2 credits load. The course as contained in book IV KKNI pjkr study school which is a description of the course is a course that examines the basic concepts of knowledge, skills and value system as well as attitude in the sport of tennis court games. This course provides knowledge and skills so that students can play tennis court sports properly and properly supported by knowledge, history, courts, fixtures, rules of the game / referee tennis court. By participating in this course students are expected to play a game of tennis with basic technical skills in the form of grip, ready attitude and standing position, basic punches (forehand, backhand, volley, serve and smash). The achievement of learning this tennis course in accordance with the Smemester Learning Plan (RPS) is that after taking this course in earnest, it is expected that students have competence in:

1. Able to properly explain the history, courts and tennis equipment, rules of the game and matches as well as the basic techniques of tennis punches properly (cognitive)

2. Able to perform basic blows of tennis game in the form of; forehand, backhand, voley, serve and smash, as well as being able to implement basic punches into the form of a game/match that is refereed well and properly. (skill).

3. Internalize academic values, norms, and ethics in learning that is shown to be minimal through honesty, discipline, cooperation, independence, joy, responsibility and social sensitivity (respect) in conducting and acting in people's lives.

\section{2) Teaching Materials Analysis}

The teaching materials available in tennis lectures in PJKR FIK Unimed majors until now are the Diktat of Tennis Courses coupled with some non-mandatory handbooks related to Basic Techniques of Tennis Games, Singles tennis strategy and teaming, as well as the College Court Tennis Referee.

The materials taught in the Tennis Court course consist of the history of the game Tennis Court, Court and Player Supplies, How to Hold a Racket, Ready Position and Standing Attitude, Basic Technique, Foot Movement, Basic Training Form for Beginners, and Tennis Referee.

3) Analysis of Student Perception of Tennis Court Courses To find out the perception of PJKR students towards Tennis courses, random questionnaires were distributed to 50 students in seventh semester in 2020 who had taken the course. Samples are obtained by random sampling techniques. Questionnaires are given online using the Google Form format, where students fill out and choose answers online as well. The rate of filling out questionnaires reached $100 \%$ because respondents in general students who are still actively attending lectures on FIK Unimed campus and are cooperative. Grades obtained in Tennis course are: 7 people obtained a grade A, 20 people obtained a $\mathrm{B}$ grade, 21 people obtained a $\mathrm{C}$ grade while 2 respondents were unwilling to answer.

Students' perception of Tennis courses analyzed related to lecture materials, suitability of exam materials with the materials taught, lecturer's communion skills, learning methods used and learning time used. In this study the assessment scale that wanted to be established was 5, where the highest score was 5 and the lowest score was 1 . So the interval scale is 0.8 and the perception category in this assessment can be divided into:
a. Very positive
$4,24-5,04$
b. Positive
$3,43-4,23$
c. Middle
$2,62-3,42$
d. Negative
$1,81-2,61$
e. Very negative
$1,00-1,81$

The results of the analysis of students' perception of the tennis course can be seen in table 4.1. 
Table 2. Analysis of Perception of Tennis Court Courses

\begin{tabular}{|c|c|c|}
\hline $\begin{array}{l}\text { Perception } \\
\text { Indicators }\end{array}$ & $\begin{array}{l}\text { Perception } \\
\text { Indicators }\end{array}$ & Category \\
\hline $\begin{array}{l}\text { Lecture } \\
\text { materials taught }\end{array}$ & 4.436 & Very positive \\
\hline $\begin{array}{l}\text { Suitability of } \\
\text { exam materials } \\
\text { with the } \\
\text { materials taught }\end{array}$ & 4.44 & Very positive \\
\hline $\begin{array}{l}\text { lecturer's } \\
\text { communion } \\
\text { skills }\end{array}$ & 4.544 & Very positive \\
\hline $\begin{array}{l}\text { Learning } \\
\text { methods used }\end{array}$ & 4.212 & Positive \\
\hline $\begin{array}{ll}\text { Learning } \\
\text { used }\end{array}$ & 4.312 & Very positive \\
\hline
\end{tabular}

From the table above it can be seen that the overall perception of students towards Tennis Court courses is very positive, and the positive perception for the learning methods used. With the procurement of this module, it is expected that students' perception of the learning methods used can be very positive.

\subsection{Product Design Stage}

The product design stage of its activities includes determining module components, the concept of material delivery and organizing, the type of task given, evaluation questions, images, articles, examples, and module layouts. This stage will result in the initial product design in the form of modules that have previously been done drafting product assessment instruments to serve as guidelines in designing products.

Module components developed following the format in accordance with the rules set by the Ministry of National Education (2008) include the opening section, the core section, and the cover section. The opening section consists of the title, foreword, table of contents, concept map, module description, module prerequisite, module usage instructions, final destination, and capability check. The core consists of material descriptions, assignments, and summaries. The closing section consists of glossary, final test, and bibliography. The modules developed contain images on each description of the material contained in the developed module. The images used are real and can be seen with eyes in everyday life such as how to hold a racket, how to swing a racket and others (figure 4.1)

The position of the body, legs and movement in all directions with the shape.it is necessary to avoid to give a heavy focal point on the heel of the foot, for that should be the body slightly leaned forward. this will result in the fulcrum being on the sole of the front foot. The head of the racket being held should always be higher than the stalk because such a standing position is also required to hit the ball especially in basic blows (open groundstroke stance, figure 4.1). The next is the positioning. This ready-to-hit time depends heavily on the slow pace of the ball from the opponent towards us. to succeed in doing the punch is always attempted to wait for the ball before the opponent's ball bounces on his own field.

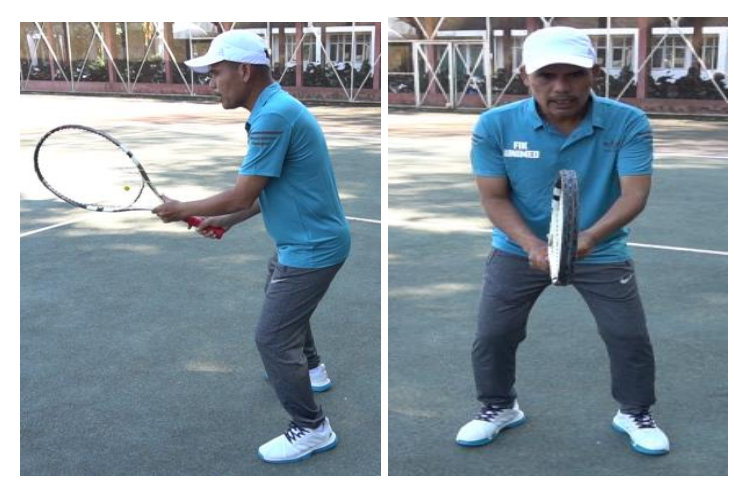

Figure 2. The use of images is real in modules

For that before the opponent performs his punch, the player must already be in a ready position. this is important because in a ready position the player can read the direction, intent.

The concept of submission and organizing of materials is adapted to RPS that has been composed, consisting of the preliminary part, the core part and the cover. The introductory section contains the expected Learning Achievements and Learning Sub-Achievements after completing the module. The Core section consists of the Subject matter and the Material Description. In this section it is systematically outlined the material delivered in the module. In this section, it is expected to be presented a module containing five characteristic modules namely selfinstruction, self-contained, stand alone, adaptive, and userfriendly. The closing section consists of evaluations, assessment instructions, individual tasks, bibliography, answer keys and glossary.

The use of images in modules is attempted using real images. The layout of the image follows rules that are matched by artificial beauty. The image format should be numbered sequentially, then if the image is captioned, the title should not exceed ten words in one image. Giving the image caption are done after exposure to the image (figure $3)$.

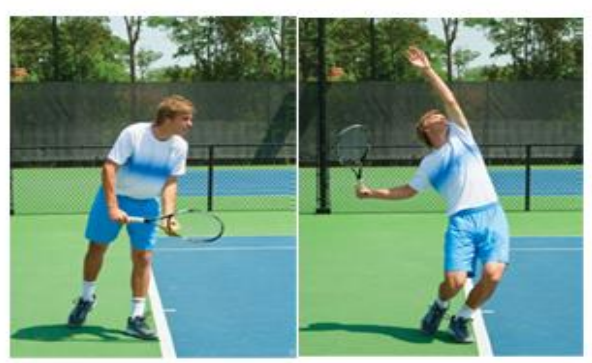

Figure 3. Image caption

The evaluation questions in the closing section are multiple choice with 5 answer options. The type of question item can be constructed so as to demand the 
ability of test taker to distinguish different levels of truth at once. All answer options must be homogeneous and possible as correct answers. The correct answer and the corrector are made similar both in terms of grammatical and theoretical concepts. Each test item is not interdependent or related to another test item.

\subsection{Validation and Evaluation Stage}

This stage is the core stage in the form of a series of product development assessments. This stage was conducted by engaging materials experts and learning media consisting of 3 lecturers of Tennis Court in FIK Unimed environment. Analysis conducted by experts is used to see the level of quality of modules seen from three aspects namely 1) the substance of materials developed in module; 2) language aspect and 3) presentation aspect. To determine the results of the analysis of the instrument data has been prepared as many as 50 questions related to the feasibility of the media to be developed.

\subsubsection{Validation stage}

Analysis conducted by experts is used to see the level of quality of modules seen from three aspects namely 1) the substance of materials developed in module; 2) language aspect and 3) presentation aspect. Recapitulation of the results and percentage of assessments conducted by pera expert can be seen in the following table:

Table 3. Expert validation recapitulation and calculation for Tennis module

\begin{tabular}{|c|c|c|c|c|c|}
\hline No & Assessed Aspects & $\begin{array}{l}\text { Many } \\
\text { items }\end{array}$ & Earnings score & Average & $\%$ \\
\hline \multirow[t]{7}{*}{$\mathrm{I}$} & CONTENT ELIGIBILITY & & & & \\
\hline & Material Coverage & 2 & 21 & 3,50 & $88 \%$ \\
\hline & Material Accuracy & 4 & 40 & 3,33 & $83 \%$ \\
\hline & Latest & 3 & 32 & 3,56 & $89 \%$ \\
\hline & Stimulating Curiosity & 3 & 31 & 3,44 & $86 \%$ \\
\hline & Contains Contextual Insights & 2 & 21 & 3,50 & $88 \%$ \\
\hline & Developing Learning Self-Reliance & 5 & 52 & 3,47 & $87 \%$ \\
\hline \multirow[t]{7}{*}{ II } & LANGUAGE COMPONENTS & & & & \\
\hline & $\begin{array}{l}\text { In accordance with the development of } \\
\text { learning }\end{array}$ & 2 & 21 & 3,50 & $88 \%$ \\
\hline & Communicative & 2 & 22 & 3,67 & $92 \%$ \\
\hline & Dialogis Dan Interaktif & 2 & 21 & 3,50 & $88 \%$ \\
\hline & Businesslike & 2 & 21 & 3,50 & $88 \%$ \\
\hline & $\begin{array}{l}\text { Coherence And The Demands of The Mind } \\
\text { Flow }\end{array}$ & 2 & 23 & 3,83 & $96 \%$ \\
\hline & Use of Symbols And Terms & 3 & 31 & 3,44 & $86 \%$ \\
\hline \multirow[t]{5}{*}{ III } & SERVING COMPONENTS & & & & \\
\hline & Serving Techniques & 4 & 40 & 3,33 & $83 \%$ \\
\hline & Supporting Material Presentation & 10 & 107 & 3,57 & $89 \%$ \\
\hline & Learning Presentation & 5 & 53 & 3,53 & $88 \%$ \\
\hline & Average & & & 3,50 & $88 \%$ \\
\hline
\end{tabular}

The average result of an expert assessment for each aspect assessed is 3.5 out of a scale of 4 or can be expressed at a percentage of $88 \%$. Thus the module developed can be said to be very feasible to use (Suharsimi, 2010).

\subsubsection{Readability Test}

The improved draft module was tested to a small group of 20 students for readability tests. The readability test results in this small group found some errors such as writing tables and inappropriate image titles and there were some typos in the draft module.

In the writing aspect, 17 students answered the writing on the module can be read clearly, in the aspect of completeness of the picture 16 students answered the completeness of the picture in the module is complete, on the aspect of understanding the material 15 students answered the module can help understand the material, on the interesting aspect of the 17 students answering the language used is easy to understand.

In blended learning, the modules developed consist of print modules for offline learning and online modules for online learning. Modules for online learning are uploaded into Unimed's online learning system (SIPDA), so students can download learning materials outside of pre-defined face-to-face hours. The display of the uploaded module can be seen in figure 4.3 and 4.4 . 


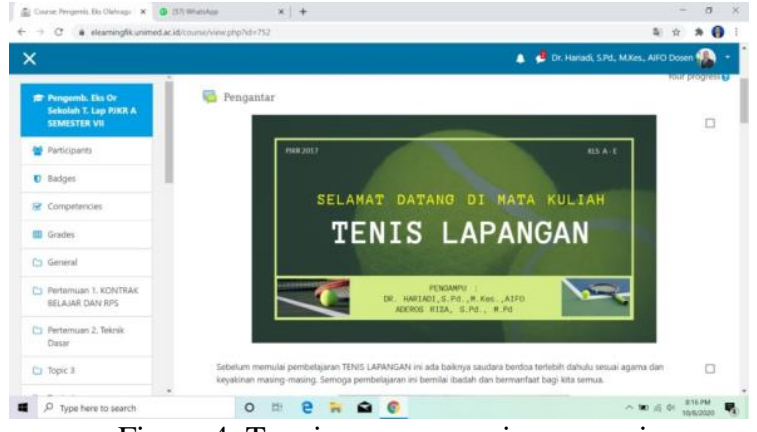

Figure 4. Tennis course opening page view

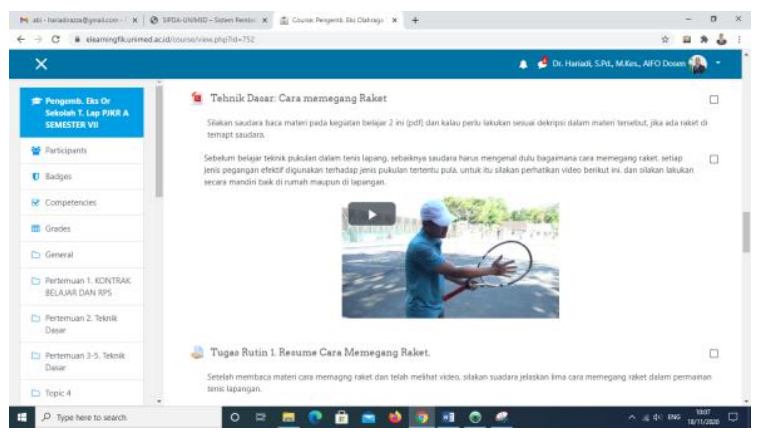

Figure 5. Display of Tennis Court Lecture Materials at SIPDA Unimed

Overall, the development of modules in tennis courses is declared feasible and can be used in learning. The validation result of the validator shows a validator perception percentage of $88 \%$ and is included in the first validation criteria which is very good. The readability test results also showed an excellent response from students to the modules developed.

\subsubsection{Final Product Stage}

The completion of the final product is done after getting the student response from the results of the product trial, then an improvement is made to the module developed based on input and advice from the expert validator and the results of the readability test in a small group. After the final product was compiled, a trial was conducted by providing a questionnaire of 50 students of PJKR FIK Unimed who were randomly selected. This trial was conducted to find out the response of students as users to the modules that have been developed. The results of the student response test to the final product of the module showed an average of 4.49 out of a scale of 5 or with a percentage of $89.9 \%$ that fall into the category of "excellent".

\section{DISCUSSION}

From the results of the analysis of the needs of teaching materials found that until now the teaching materials of Tennis Court Courses in the FIK Unimed environment only use diktat courses and some other books that are not required by students. Analysis of student perception of Tennis Court currencies is conducted by providing a questionnaire to students that shows that in general. student perception of Tennis Court courses is very good with an average of 4.38 out of a scale of 5 which means "very positive". The lack of teaching materials for Tennis Court courses makes it possible to provide a prison learning module. Thus the module is expected to help students to more easily learn and understand the materials on the course Tennis Court.

After the design of the module that produced the draft module, the expert validation results showed an average of 3.5 out of a scale of 4 with a percentage of $88 \%$. The results of expert validation of the draft module can be said to be very good, the highest value on the aspect of coherence and the demands of the thought flow that reaches the number of $96 \%$. The suitability of the module and the coherence and demands of the thought flow are expected to stimulate student curiosity and provide ease in understanding each subsection of the material but remain coherent with the other sub-sections in the Tennis Court course. Expert validation results also showed that the suitability of this module to stimulate curiosity reached $86 \%$, developed learning independence at $87 \%$, and conformity with the development of learners reached $88 \%$. This is in accordance with the criteria of the module which is a systematic and interesting teaching material that includes teaching materials, methods and evaluations used independently (Mudlofir, 2011), assists students individually in achieving their learning goals (Sukiman, 2011), and consists of a series of learning activities arranged to help students achieve specially formulated and also clear goals (Nasution, 2010)

In the readability test on the writing aspect, 17 respondents answered the writing on the module can be read clearly, in the aspect of the completeness of the image, 16 respondents answered the completeness of the image in the module is complete, on the aspect of material understanding, 15 respondents answered the module can help understand the material, on the aspect of attractiveness, 17 respondents answered the language used easily. The results of this readability test show that the modules developed in this study are already worth using, and already meet the characteristics of the module as a teaching material systematically composed with a language that is easy to understand by students, according to their age and level of knowledge so that they can study independently with minimal guidance from educators (Prastowo, 2012).

The results of large-scale trials conducted by presenting questionnaires to students as prospective module use showed a positive response. Test results on the module's final product showed an average of 4.49 out of a scale of 5 or with an $89.9 \%$ percentage that fall into the "excellent" category. Thus the field module tennis court that has been developed by following the steps of the development module in this research is stated to be widely 
used in the learning of Tennis Court in FIK Unimed in particular as well as other parties who need it.

\section{CONCLUSIONS AND SUGGESTIONS 8.1 Conclusions}

Based on the results obtained in the steps of this study can be concluded that the tennis module produced based on the module development measures in this study is a module worth using in learning.

\subsection{Suggestions}

\section{- Utilization Advice}

The use of this learning module in Tennis course requires adjustment to the student's learning pattern, so it is necessary to study the time planning at the beginning of the semester before the study begins in order for the implementation process to run properly.

- Dissemination Suggestions

With the many positive responses and suggestions given, this module should still be refined in order to be accepted by various parties in need.

Since the module developed today still only includes the discussion of the Tennis Court module, then a) further development is expected to include discussion of all courses in PJKR FIK UNIMED as the basis of module development, b) the many stages passed in the module development process, should be done carefully, carefully and openly, ranging from the preliminary analysis stage to the validation test and field test stage, c) the language aspect should be considered because it is one of the important elements that can make it easy for module users to understand the material submitted.

\section{REFERENCES}

Astiti, N; Pudjawan K and Wirya, N. 2014. Pengembangan Modul Pembelajaran Matematika Di SMP Negeri 1 Banjar Untuk Siswa Kelas VIII Semester Genap. Jurnal Edutech Vol 2, No 1 (2014)

Dwi S, Woro, S., and Saptorini. 2014. Efektivitas Model Inkuiri Berbantuan Modul dalam Meningkatkan Pemahaman Konsep dan Keterampilan Generik Sains. Jurnal Inovasi Pendidikan Kimia Vol 8, No 2

Herman, L; Subchan, W and Wahono, B. 2016. Pengembangan Modul Berbasis Masalah pada Pokok Bahasan Ekosistem Kelas VII SMP/MTs. Jurnal Edukasi Universitas Jember Vol 3, No 3: Nopember 2016

Husna A., Sudarmin dan Latifah. 2013. Pengaruh Model Pembelajaran Quantum Teaching Berbantuan Modul Qt-Bilingual Terhadap Hasil Belajar Siswa. Jurnal Inovasi Pendidikan Kimia Universitas Negeri Surabaya Vol 7, No 2

Mudlofir, A. 2011. Aplikasi KTSP dan Bahan Ajar dalam Pendidikan Islam. Jakarta: Raja Wali Press.

Nyimas, A, and Purwoko. 2011. Peningkatan Hasil Belajar Mahasiswa Menggunakan Modul. Jurnal Ilmu Pendidikan Universitas Negeri Malang Vol 17, No 5

Rose, R A, and Prasetya, A T. 2017. Keefektifan Strategi
Project Based Learning Berbantuan Modul Pada Hasil Belajar Kimia Siswa. Jurnal Inovasi Pendidikan Kimia Vol 8, No 2

Sungkono, 2012. Pengembangan Instrumen Evaluasi media Modul pembelajaran. Jurnal Majalah Ilmiah Pembelajaran no. 2 thn. 2012:

Krasnova T. A Paradigm Shift: Blended Learning Integration in Russian Higher Education. Procedia Social and Behavioral Sciences, 2015, no. 166, pp. 399-403.

Kintu, Mugenyi J, et.al. 2017. Blended learning effectiveness: the relationship between student characteristics, design features and outcomes. International Journal of Educational Technology in Higher Education, 2017, no. 7, pp.

Abubakar, D. and Adetimirin. 2015. Influence of computer literacy on post-graduates' use of e-resources in Nigerian University Libraries. Library Philosophy and

Practice. From http://digitalcommons.unl.edu/libphil prac/. Retrieved 18 Aug 2015.

Goyal, E. and Tambe, S. 2015. Effectiveness of Moodleenabled blended learning in private Indian Business School teaching NICHE programs. The Online Journal of New Horizons in Education, 5(2), 14-22.

Osgerby, J. 2013. Students' perceptions of the introduction of a blended learning environment: An exploratory case study. Accounting Education, 22(1), 85-99.

Oxford, G. 2013. Blended learning-current use, challenges and best practices From http://www.kineo.com/m/0/blended-learningreport-202013.pdf . Accessed on 17 Mar 2016.

Kwak, D. W., Menezes, F. M., \& Sherwood, C. 2013. Assessing the impact of blended learning on student performance. Educational Technology \& Society, 15(1), 127-136.

Hedin, Bjorn \& Kann, Viggo. Improving Study Skills by Combining a Study Skill Module and Repeated Reflection Seminars. Education Research International. Volume 2019. https://doi.org/10.1155/2019/9739854

Gaikwad, N. and Tankhiwale, S. 2014. Interactive Elearning module in pharmacology: a pilot project at a rural medical college in India. Perspectives on Medical Education.

Damrah, P., and Suwirman. 2018. Evaluasi Program Pembelajaran Tenis Dasar Semester Ganjil 2018 Fik Unp. Jurnal Menssana, Volume 3, No 1, May, 2018

Nurpratami, H., Farida, I. C. dan Helsy, I. 2015. Pengembangan Bahan Ajar pada Materi Laju Reaksi Berorientasi Multipel Representasi Kimia. Prosiding Simposium Nasional Inovasi dan Pembelajaran Sains: 353.

Risa Agus Teguh Wibowo. 2017. Perbedaan Pengaruh Model Pembelajaran Berganti dan Pengulangan Terhadap Kemampuan Pukulan Grounstroke Backhand Tenis Lapangan Ditinjau dari Koordinasi Mata-Tangan. Jurnal Ilmiah Penjas. Volume 3 NO. 2 (2017) 